\title{
International Map Year: Results and Implications
}

\author{
Bengt Rystedt ${ }^{\mathrm{a}}$, Ferjan Ormeling ${ }^{\mathrm{b}}$, Aileen Buckley ${ }^{\mathrm{c}}$, Serena Coetzee ${ }^{\mathrm{d}}$, Vit Voženilek ${ }^{\mathrm{e}}$, David \\ Fairbairn ${ }^{\mathrm{f}}$, and Ayako Kagawa ${ }^{\mathrm{g}}$ \\ ${ }^{a}$ Bengt Rystedt. Retired from National Land Survey of Sweden and University College of Gävle, Sweden. bengt@rystedt.se. \\ ${ }^{b}$ Ferjan Ormeling. Professor Emeritus of Cartography at Utrecht University, Netherlands. f.j.ormeling@uu.nl. \\ ${ }^{c}$ Aileen Buckley. Research Cartographer at Esri, Redlands, California, USA. abuckley@esri.com. \\ ${ }^{d}$ Serena Coetzee. Professor of Geography at University of Pretoria, South Africa. serenacoetzee@gmail.com \\ ${ }^{e}$ Vit Voženilek. Professor of Cartography at Olomouc University, Czech Republic.vit.vozenilek@upol.cz. \\ ${ }^{f}$ David Fairbairn. Senior Lecturer in Geomatics at Newcastle University, UK. david.fairbairn@newcastleac.uk. \\ ${ }^{g}$ Ayako Kagawa. Geographic Information Officer at the UN Cartographic Section, New York, USA. kagawa@un.org.
}

\begin{abstract}
IMY was a worldwide celebration of maps and their unique role in our world. Supported by the United Nations, IMY provides opportunities to demonstrate, follow, and get involved in the art, science, and technology of making and using maps and geographic information. International Map Year (IMY) started in Paris 2011 when the General Assembly of the International Cartographic Association (ICA) asked the ICA Executive Committee (EC) to follow up on the proposal given in a motion from the Swedish Cartographic Society. An IMY Working Group (WG) was constituted-it defined the IMY goals and the activities required to reach them, and it proposed a suitable time period for the IMY to the ICA EC. IMY commenced in August 2015 and ended in December 2016. The success of IMY was dependent on all member nations of the ICA participating in an effort to broaden the knowledge of cartography and geographic information in society in general, especially among citizens and school children. Member nations of the ICA were responsible for organizing IMY activities, such as a national Map Day, through national IMY committees tasked to engage national organizations and spearheading collaboration. The IMY WG set up an IMY web site with general information on IMY, guidelines for how to organize Map Days, suggestions relating to activities aimed at general map awareness, and more. The web site also provides access to the electronic book The World of Maps, which has been translated from English into five other languages.
\end{abstract}

Keywords: International Map Year, IMY, The World of Maps, maps, geographic information

\section{Introduction}

International Map Year (IMY) 2015-2016 was a worldwide celebration of maps and their unique role in our world. Initiated by the International Cartographic Association (ICA) and supported by the United Nations (UN), IMY provided opportunities to demonstrate, follow, and get involved in the art, science, and technology of making and using maps and geographic information.

While it is for others to judge whether IMY was successful, it is a fact that extraordinary cartographic activities occurred during this event. The public was offered a variety of free resources downloadable from the IMY web site (http://mapyear.org/) to help it celebrate the event and organize related activities. These resources included a blog to share news about happenings around the world, suggestions for how to host a variety of maprelated events, guidelines for how to organize a national Map Day, logos for t-shirts and buttons, and a variety of other promotional materials. A free e- book on cartography, called The World of Maps (http://mapyear.org/the-world-of-maps-overview/), was also made available along with translations of the book from English into five other languages. The hope is that all of this activity has generated more interest in maps and encouraged young people to consider a career in a cartography-related profession. Consequently, the Executive Committee (EC) of the International Cartographic Association (ICA) decided to continue the effort to promote cartography and geographic information by co-ordinating an annual international Map Day in the future.

\section{History}

The concept of IMY was presented by ICA representative Prof. William Cartwright in November 2011 at the UN Regional Cartographic Conference for Asia and the Pacific in Bangkok. Cartwright also presented a tentative resolution. The conference adopted the proposed resolution stating that the ICA should organize IMY so that it would commence in 2015 . The resolution read as follows:

The conference,

Recognizing the enormous benefit of reliable and authoritative geospatial information and maps in decision making for sustainable use of natural resources, economic development and for community well-being;

Noting the need to promote geospatial information education and training for national governments, decision makers, the geospatial industry and users;

Also noting the preparations made by the International Cartographic Association ad-hoc committee for the International Map Year, and the support by the Joint Board of Geospatial Societies (JB-GIS) on this initiative; 
Recommends the International Cartographic Association (ICA) to organize an International Map Year in 2015.

During a telephone conference between representatives of the UN Cartographic Section and the ICA in February 2012, it was decided that the ICA should propose that IMY be included in the work of the UN Committee of Experts on Global Geospatial Information Management (UN-GGIM), which is the UN body charged with making maps and geospatial information available in UN-related activities around the world. Members of the UN-GGIM are representatives of national mapping organizations and members of the Joint Board of Geospatial Information Societies (JBGIS). As a result of the above activities, the ICA formed an IMY Working Group (WG) in 2011 to act as an organizing body to plan and promote IMY.

At the 2013 International Cartographic Conference (ICC) in Dresden, Germany, the ICA EC decided to extend the timeframe for IMY to include 2016 so as to incorporate the 2015 Barbara Petchenik Children' Map Competition, organized by the ICA, into the IMY schedule of events. Although IMY began in January 2015, the official IMY inauguration occurred during the Opening Ceremony of the 2015 ICC in Rio de Janeiro, Brazil. Gregory Scott, of the UN-GGIM, led the inauguration, assisted by George Gartner, president of the ICA at that time, and Bengt Rystedt, chair of the IMY WG. At the 2015 ICC, all conference participants received a t-shirt with the IMY logo, which was designed by the ICA webmaster, Manuela Schmidt. These t-shirts have since appeared around the world, as shown in figure 1, where ICA commission chairs posed for a picture in Vienna, Austria.

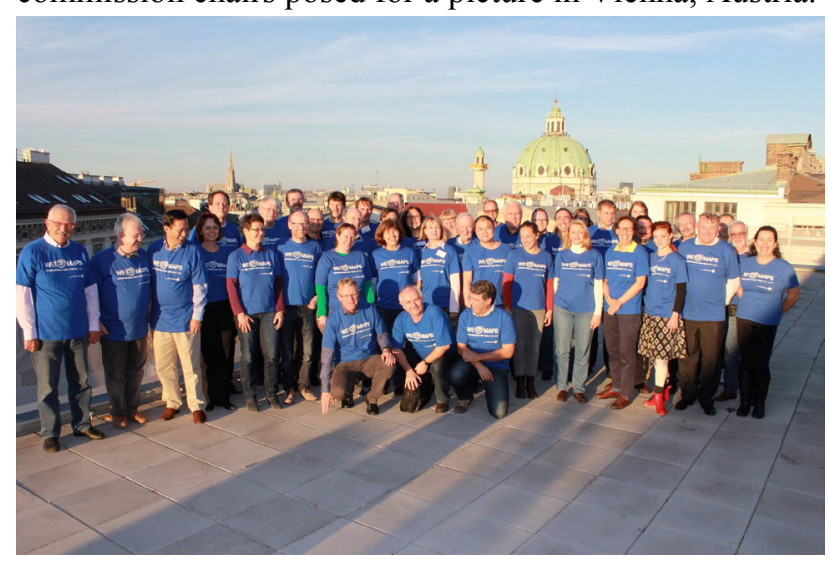

Figure 1. The IMY t-shirt was prominent at the ICA Commission Chairs meeting in Vienna, Austria, in November 2015. Participants included ICA EC and the chairs and vicechairs of the ICA commissions and working groups.

\section{The IMY Working Group}

The IMY WG Terms of Reference, presented at the 2011 International Conference (ICC) in Paris, France, and accepted by the ICA General Assembly, read:

- Create a textbook on cartography and geographic Information for the general public;

- Elaborate plans for national activities and establish national contacts;

- Involve the ICA commissions in the work;

- Find sponsors among the affiliate members;
- Establish contacts with the UN and sister organizations (through the ICA EC and the JBGIS);

- Produce information that can be used for national Map Days;

- Follow up on and update the working plan at the ICC in Dresden 2013.

The IMY terms of reference also included the terms required of all ICA commissions and working groups, such as setting up a web site and regularly providing information to the ICA EC and for the ICA newsletter.

\subsection{The IMY web site}

As mentioned above, one of the terms of reference for all ICA commissions and working groups is to establish a web site. The initial steps to develop this site were taken at an IMY WG meeting in Olomouc, Czech Republic, in February 2014. The mockups and much of the content for the web site pages were developed by IMY WG member Aileen Buckley. Additional content for the site was compiled by IMY WG member David Fairbairn from a paper he presented to the International Society for Photogrammetry and Remote Sensing Technical Commission VI Symposium in Wuhan, China, in March 2014 (Fairbairn, 2014). That paper was also presented by IMY WG member Ferjan Ormeling at a meeting of UN Group of Experts on Geographical Names at the UN headquarters in New York, NY, USA, in June 2014 (Fairbairn and Ormeling, 2014). It was also presented a few days later to Gregory Scott, Inter-Regional Advisor on Global Geospatial Information Management in the UN Statistics. Through these outlets, the IMY information initially compiled in Olomouc began to spread widely.

The IMY web site was originally created in the Department of Cartography and Geoinformatics of the Eötvös Loránd University of Budapest. The web site was then redesigned by Schmidt at the Technical University in Vienna, Austria, who continues to manage the site. The IMY web site was launched in 2014 and has been updated regularly ever since. Although IMY has ended, the web site remains accessible to provide continued access to The World of Maps e-book and other resources and to support future national Map Days.

\subsection{Organization of the web site}

The IMY web site includes the following sections: News, About, Get Involved, Events, and The World of Maps. The News section is the landing page for the web site. It contains a blog with posts from participating countries to high-light their IMY national activities (figure 2) and other activities that have been organized at the international level by the ICA and its members. These ICA activities include the creation of posters by the ICA commissions about how cartography can support work on the seventeen UN sustainable development goals. More details about the development goals can be found at http://www.un.org/sustainabledevelopment/blog/2015/12/ sustainable-development-goals-kick-off-with-start-ofnew-year/. 


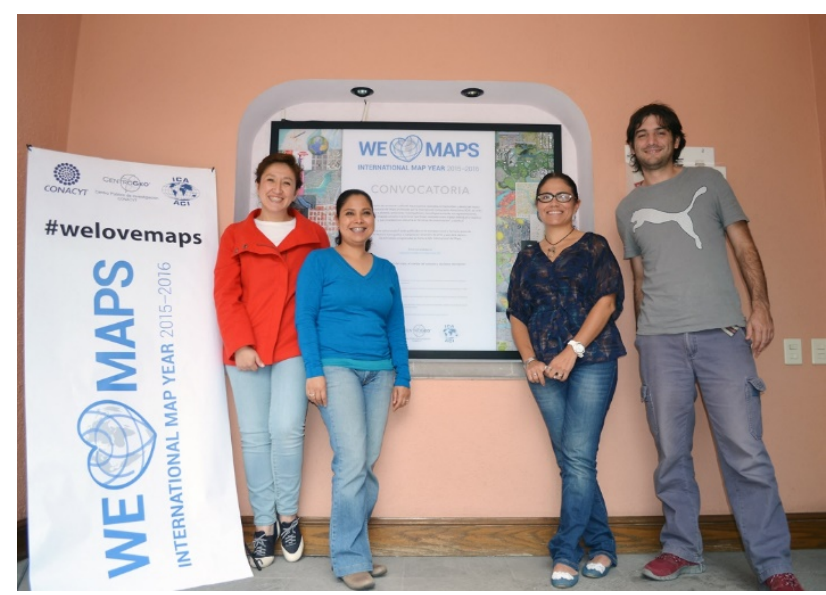

Figure 2. Members of Mexico's CentroGeo IMY Committee include (from left to right) Gabriela Quiroz, Gabriela Lopez, Yezmín Calvillo, and Jose Alavez. (Source: News page of the IMY web site).

In the About section of the web site, the purposes of the worldwide celebration of maps are stated. These include making maps visible to citizens and school children in a global context, demonstrating how maps and atlases can be used in society, and showing how technology can be used in collecting geographic information and producing maps. The About section also describes how one of the key reasons for organizing IMY was the ICA's desire to increase the recruitment of students to cartography and cartography-related disciplines and to boost the identity of ICA and its mission.

In the Get Involved section of the web site, guidelines for how to set up a national IMY committee are provided, its possible membership or composition are described, and its possible activities are outlined. These activities include setting up a web site, identifying national capacities in cartography and geographic information, identifying potential local organizers, and identifying industrial partners. For IMY to have a lasting influence, each national committee was encouraged to discuss the establishment of a future national Map Day and the further development of a national strategic plan for the creation and dissemination of geographic and cartographic information. In the Get Involved section of the web site, there is also a link to list of more than 40 countries that have already set up a national IMY committee and participated in IMY.

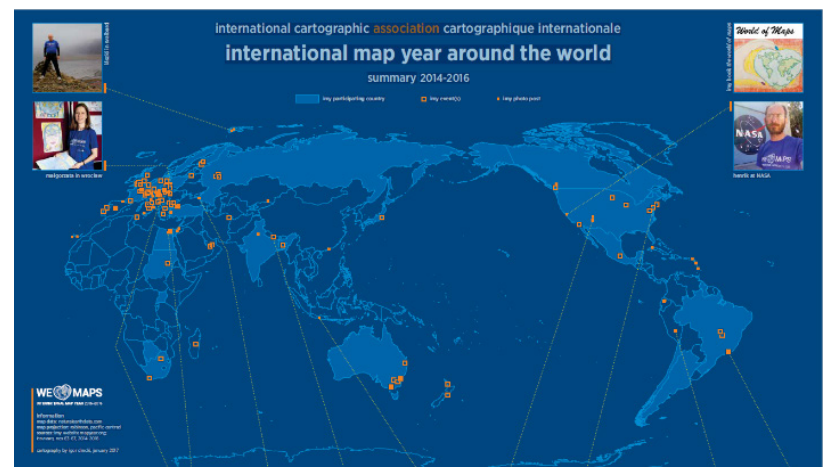

Figure 3. IMY activities around the World. Source, Drecki, 2017.
The Events section of the web site provides access to a calendar of past IMY events (figure 3).

The final section of the web site provides access to the ebook, The World of Maps, which is described in greater detail below.

\subsection{The World of Maps}

The World of Maps describes what cartography and geographic information systems are all about. It includes chapters covering a wide range of cartographic topics to form a coherent introduction, reference volume, and work-book for those who are interested in learning more about the nature of mapping and geographic information in our world today. The goal of the book is to broaden the knowledge of cartography and geographic information among the public and especially among school children. The book clearly reflects its authors' desires to share their love of maps. The book has the following chapters by the authors noted:

Preface. Georg Gartner, President of ICA

Foreword. Working Group

Introduction and Summary

1)Cartography. Bengt Rystedt, Sweden

2)Use of Maps and Map Reading. Ferjan Ormeling, Netherlands

3)Geographic Information. Bengt Rystedt, Sweden How to Make Maps

4)Map Design. Vit Voženilek, Czech Republic

5)Topographic maps. Bengt Rystedt, Sweden

6)Thematic Maps. Ferjan Ormeling, Netherlands

7)Atlases. Ferjan Ormeling, Netherlands

8)Geographical Names. Ferjan Ormeling, Netherlands

9)Map Projections and Reference Systems. Miljenko Lapaine, Croatia, and Lynn Usery, USA

How to Use Maps

10) Map Use at the United Nations. UN Cartographic Section

11) Setting One's Course with a Nautical Chart. Michel Huét, Monaco

12) Maps for Orienteering and for Finding the Cache. Lazlo Zentai, Hungary

How to Present Maps

13) Printing Maps. Bengt Rystedt, Sweden

14) Web and Mobile Mapping. Michael Peterson, USA

Geographic Information

15) Geographic Information, Access, and Availability. Aileen Buckley, USA, and Bengt Rystedt, Sweden

16) Volunteered Geographic Information. Serena Coetzee, Republic of South Africa

Education and Further Information

17) Education. David Fairbairn, UK

18) Tactile Cartography. Edwin Hunt, Chile

19) Further Information 
Presently, members of the Italian cartographic society are producing an additional chapter on the construction and use of geological maps that will be added to Chapter 5, Topographic Maps.

To the delight of the ICA EC and the IMY WG, the ebook has been translated into French, Spanish, Italian, Portuguese, and Hungarian. It is currently being translated into German, Chinese, Arabic, and Indonesian as well. As a result, apart from Russia and parts of Asia and Africa, the book will be accessible to most inhabitants of the world in their own language. Up to December 2016 the e-book web page has been visited almost 25,000 times.

\section{Conclusions}

The successes evidenced during IMY 2015-2016, such as the cooperation demonstrated for organizing national events and national Map Days in various countries, the increased interest by the general public and schoolchildren in the cartographic profession and in the use of maps, and the popularity of The World of Maps ebook, are all indicators of the need to continue the IMY initiative in some form. One idea currently being explored is the organization of an international Map Day. This and other possibilities will be discussed at the ICC in Washington, DC, USA, in July 2017.

\section{Acknowledgements}

The IMY WG is grateful to Manuela Schmidt for performing the task of webmaster of the IMY web site, for her continuous adding of news, and for the design of the IMY logo. We are also grateful to the writers of the various chapters of The World of Maps and to the translation teams, members of the ICA Executive Committee and ICA Commission Chairs, as well as the UN-GGIM and JBGIS.

\section{References}

Drecki, I. 2017 IMY around the World. ICA News No 67 pp. 12-13. Available online at http://icaci.org/ica-news/.

Fairbairn, D. 2014 The Role of Education in the International Map Year, 2015/16, International Archives of the Photogrammetry, Remote Sensing and Spatial Information Sciences, Volume XL-6, pp. 19-23. Available online at http://www.int-arch-photogrammremote-sens-spatial-inf-sci.net/XL-6/19/2014/ (accessed February 6, 2017).

Fairbairn, D. and F. Ormeling. 2014. The International Map Year 2015/16, United Nations Group of Experts on Geo-graphical Names, Working Paper, No. 76/5, Twenty-eighth session, New York, April 20 to May 2, 2014. Available online at http://unstats.un.org/unsd/geoinfo/UNGEGN/docs/28thgegn-docs/WP/WP76 fairbairn2_template-BR-2.pdf (accessed February 6. 2017). 